DOI: https://doi.org/10.3126/njdrs.v16i0.31531

\title{
Consumer Committees in Tensions? A Intrepretive Case of Lalitpur Metropolitan City, Nepal
}

\author{
Devendra Adhikari* and Rajan Binayek Pasa, PhD** \\ *PhD Scholar at Waikato University, New Zealand and the member of The Alumni Committee in \\ Central Department of Rural Development \\ **Faculty, Central Department of Rural Development
}

Corresponding email: devendra.adhi84@gmail.com and rajan.pasa@cdrd.tu.edu.np

\begin{abstract}
The people of Nepal have witnessed several political/social transformations in the country, which have resulted in the restoration of peace, the promulgation of the new constitution. The restructuring of the country into 753 local units has led to the substantive devolution of the 22 power power/jurisdictions from the center to the local governments. In this scenario, the local governments implement their development plans through consumer committees by mobilizing the local beneficiaries. The purpose of this paper is to explore the difficulties faced by these novice committees in getting development funds from the local governments even in urban cities. The paper is based on a qualitative study with an interpretative case study design. The study has revealed that the chaos of bureaucratic hurdles to receive the development budgets from the Metropolitan office is demoralizing the community volunteers at local levels. Local government should facilitate the fund releasing process to the consumer committees by easing the rules and regulations. There must be a shared governance system between the local government and beneficiaries so that both parties feel a shared responsibility to achieve any development goals. Likewise, the government should have the lead governance towards the banking institutions. Banks are the mediators between the government and the consumer to make the fund-releasing process becomes swifter and less complicated. The findings of this study could be useful in framing appropriate plans/policies for the local governments, to encourage the community people to participate as volunteers in local development projects.
\end{abstract}

Key words: Local government, novice consumer committees, interpretive case study

\section{Background}

The Constitution of Nepal 1990 had stated that the people of Nepal could enjoy their democratic rights through the wider participation in the governance of the country and the decentralized service deliveries and development works (Government of Nepal [GoN], 1990). It was the historic achievement of the people of Nepal to incorporate their voice of change, in the new constitution after the first People's movement in 1990. The constitution also confined the absolute monarchy within the constitutional supremacy. However, the political parties were blamed to misuse the multiparty democratic system and kept focused on promoting their vested interests. This ignited the birth of the Maoist war, which continued for ten years. Eventually, the country also witnessed the "autocratic, authoritarian, and unconstitutional" rule of King Gyanendra (Tripathi, 2016). Therefore, the institutionalization of the change and reforming the people-centered governance system could not blossom due to the political turmoil in those decades. 
After 1990, though the then constitution provided enough space for practicing the decentralization process in Nepal, there were some policy hurdles in implementing people-centered development in the newly democratized Nepal. The local bodies were not provided full autonomy to function as they were financially dependent on the central government (Adhikari, 2010). The local government units were also politically unstable, and they lacked the technical competencies to deal with different development issues of the people. There were issues in the participatory development practices and inclusive development system. Besides, there was a dual accountability system of the local governments, firstly upward accountability towards the concerned department and ministries, and secondly the downward accountability towards the people who elected them. To our dismay, the accountability towards the common people was almost forgotten and the local bodies seemed more loyal towards the central political powers.

In 1999, the Local Self-governance Act 2055 was introduced as an important milestone in Nepal's local development history. The act included the devolution of power, responsibilities, and means of resources to make local bodies efficient in local self-governance. It had mentioned in developing local leaderships for making the local governments accountable towards the people. The emphasis on people's participation in development activities was one of the major outlining of the act (GoN, 1999). The act was the initiation of the Government in bridging the gap between the state and citizens by delegating autonomy to the local bodies.

The emptiness of the elected representative from the period of 2002 to 2016 was the dark era of local development in Nepal. There was no local level election and the bureaucrats were representing the local bodies. There was a kind of political emptiness at the local levels during the period. Chalise and Varughese (2017) explain that the sharing of power with local bodies as envisaged by the Local self-governance Act was shadowed due to the constraints in resources and capacities, and as well as by a decade-long conflict from 1996 to 2006. Almost all the local as well as the central level development activities were nearly paralyzed during that period. After the people's movement in 2006, the newly promulgated the Interim Constitution of Nepal 2007 focused on political consensus between the leading political parties to pass any constitutional bills by the legislature (Government of Nepal, 2007). This introduced a provision of an All-party mechanism at local governments in allocating the development budgets, due to which the government officials were compelled to work under syndicate of the political parties (Chalise \& Varughese, 2017). The political consensus system weakened the governance system in Nepal and promoted local corruption because of there was no oppositions, no check and balance provisions, and only harsh power games.

The political shift after people's movement in 2006 succeeded in promulgating, the Constitution of Nepal, 2015 which declared Nepal as a Federal Democratic Republic Country. The unitary governance system has been dissolved and the ruling power and authority have been decentralized to the states and local units (GoN, 2015). With this, the country has been restructured into seven provinces, 753 local governments having 276 Municipalities, 460 rural municipalities, and 6343 wards (GoN, 2018). The local governments have got the constitutional right to conduct local development programs and projects. Thus, with the promulgation of the new constitution in 2015 , the centrally practiced system of planning, budgeting, and implementing the local level plans have been formally ended and a new era of development has begun. 
According to the Fourteenth Plan of Government of Nepal, the development activities which have direct relations with the livings of the people should incorporate their meaningful participation (Nepal National Planning Commission [NPC], 2016). The meaningful engagements of the beneficiaries at all stages of the development works such as need identification, planning, implementation, monitoring and evaluation, and benefit-sharing, could only bring people-centered development (Chambers, 1983).The mobilization of local people also enables their capacity to do the economic management of development activities locally and independently. The local people will facilitate their participation through different social interactions. The fourteenth plan has stressed on increasing the people's participation at every level of development activities and service delivery. In this scenario, the Government of Nepal conducted all three tiers of elections in 2017 and the elected representatives have been performing their activities as per the constitutional provisions. These activities have represented the people's voice for the progressive change that probably reshapes their fate.

From the period of 1990 to 2017, people witnessed different political and social turmoil in Nepal which has succeeded in restoring the peace, promulgation of the new constitution by the constituent assembly, and restructuring of the country into 753 local units. The substantive devolution of power and resources from the central government to the local government has increased hope and expectations among the people. The constitutional provisions will ensure the participation of local people in every development plan and policies that outline their fate. In this scenario, the local development activities are rapidly undergoing, mostly by the involvement of the beneficiaries through the Local Consumer Committees.

\section{Research Gaps: Challenges for Efficient Local Development Initiation}

The Government of Nepal (2017) has introduced the Local Government Operation Act 2017 to implement the provisions of the rights of local governments as set out in the constitution of Nepal 2015. The Act includes the categories of the services and development activities, which the local government must deliver to the people. The Act has identified the ward as the grass-root level local body, with the responsibility to plan, monitor, and implement the development activities inside the ward. The ward committees must follow the participatory development model in the annual plan preparation process. The committees must collect the development demands from the settlements through consulting widely. The act has mentioned that the ward offices should facilitate in the forming of the Tole Development Committees in every settlement and these committees should be mobilized in the local projects. These constructive notions of decentralization are oriented towards empowering the locals through "local governance" rather than the "local management" (Hope, 2000, p. 1).

Delegation of administrative authority from the central government to the local bodies had been envisioned that the development works would be completed by time, with quality works, and bear fewer problems during their implementation. It was expected that there would be meaningful participation of the locals in the monitoring and evaluations of the community level development activities. It was envisaged that the development activities which operate with less budget, should be performed by the local consumer committees using locally available resources and technologies, without hiring contractors. However, the reality is different as the development activities initiated by local consumer committee groups are not completed on time and the monitoring and evaluations have become ritualized only. The bureaucratic process is much chaotic, due to which it appears that the 
common people do not like to do volunteer work in local development activities and participate $\mathrm{g}$ in local consumer committees.

Despite the policy provisioning of giving full authority to the local peoples and local government to design, implement, and do monitoring and evaluation of the local works, there are problems in the timely completion of the local development activities. We have witnessed that the local people are afraid of participating in local consumer committees and work as volunteers in development activities. Thus, the purposes of this study are to explore how the consumer committees are formed and what hurdles they face to get the allocated budget from their local government.

\section{Objectives}

- To look at on information dissemination and consumer committee formation process while getting development fund from local government.

- To look at on post agreement process and banking hurdles faced by consumer committee members.

- To appraise organizing, mobilizing and networking process of the consumer committee members during project implementation.

\section{Research Methodology: An Interpretive Case Study Approach}

This paper follows the interpretive case study research design. We have studied the lives of the individuals, asked them to provide stories of their life, and used the interpretation of those stories to address the concerns raised by this research (Willis, 2007). Yin (2011) has defined the case study as "an empirical inquiry which investigates a contemporary phenomenon (the case) in depth and within its real-world context" (p. 16). This method relies on "multiple sources of evidence, with data needing to converge in a triangulating fashion" such as in-depth interviews and observation (Yin, 2011, p. 17).

We followed unstructured interviews and observation methods for information collection. We visited the study sites and interacted several times with the members of the local consumer committees of ongoing development activities. We selected three participants based on judgmental sampling who was Chairperson- $A$ and Secretary from a consumer committee-A, which was assigned to fence a temple premise. Another participant was the Chairperson-B from committee-B, which was laying stones at another temple premises. We did in-depth interviews, listened to their stories, and interpreted them with the help of the theories, literature, and our self-reflections.

In this research, the case was a ward in the Lalitpur Metropolitan city, where the development plans were ongoing from the annual budget of the Metropolitan city office for the fiscal year 2074/75 $(2018 / 19$. The ward was chosen as the case as it is the smallest geographical division of the local government, which is led by the elected representatives. The units of analysis are the two consumer committees formed in two different settlements for implementing the plans. The narrations of the participants who were actively involved in the consumer committees were interpreted to make out the meanings More so, the meanings are aligned with the research objectives and are informed by the theory of organization and network governance.

\section{Theoretical Interpretation: Organization Theory}

According to Dinitzen and Jensen (2010), a team comprises different individuals with their skills and potentiality. All the members in a team are supposed with the shared interests are believed 
to stand together to overcome any institutional difficulties and achieve the common goal. The synergy in a team always motivates its members to orient their focus towards the outputs. The group can be effective if it has team performances, which aligns with the "context, composition, job design, and process" (Robbins \& Judge, 2009, as cited in Dinitzen \& Jensen, 2010, p. 48). The authors further clarify that the context reveals to the supportive environment for the team having enough access to resources. In composition, people from different backgrounds with diverse skills and know-how can address the problems with the combined effort. In job design, the people have the autonomy to utilize their abilities, so that a sense of ownership is developed among them. In the process, different guiding rules must be prepared for minimizing the conflicts within the team and orienting all the team members towards achieving the common goal.

\section{Network Governance Theory}

Halgin (2012) has pointed out that society is made up of a network between individuals called nodes, which are tied to each other through different types of interdependencies with each other. This type of relationship builds a network, which solves different problems of individuals and helps each other to achieve the desired goal. The network also comprises the different organizations in a society with common societal interests. Pravan and Kenis (2007) have shared that there are three models of governance models acting efficiently, which are shared governance, lead organization governance, and network administrative organization. In the shared governance, the network members do not have separate governance entities as all are equally responsible for managing internal as well as external relations and overcome any issues together. In the lead organization governance, all major activities and decisions making are done by a single powerful organization within it. In the network administrative organization, the members form a network with the defined key roles and responsibilities of the individuals, to coordinate within and sustain the network. Among the three models, the shared governance model is appropriate for local development works in Nepal because the participants in this model also do not need a high level of competencies due to shared responsibilities to cope up with any issues. Thus, with the uses of the above-mentioned theories, we have interpreted the stories of the experiences of our participants by generating the themes which are discussed below.

\section{The Results: Information Dissemination and Consumer Committee Formation}

Lalitpur Metropolitan City is one of the 753 local government units in Nepal which is politically divided into 29 wards. In the fiscal year 2018/19 (2075/76), the Metropolitan office had allocated a budget of NRs. 7,00,000 under the heading of the temple and paati ${ }^{1}$ repair work for a settlement in the ward no. 14. The ward engineer did a field survey and estimated the work details, which increased the budget to NRs. 7, 70,000. The Metropolitan office was bearing NRs. 7, 00,000 and the local beneficiaries had to invest NRs. 70,000 as peoples' participation fund. These details could be observed on the hanging banner at the temple premise.

The settlement where the temple lies also has a Guthi ${ }^{2}$ to perform different social and cultural activities. The Guthi has its monthly meetings on the sixteenth of every Nepalese month at the Mahalaxmi temple premise. In December 2018, the local people were gathered in the Guthi meeting as

1 Resting public place

2 Indigenous social and cultural organization

Nepalese Journal of Development and Rural Studies, Volume 16, 2019 
usual. They got news from the ward office that the Metropolitan office had allocated some money for the temple fencing works. The Central government had allocated the nationwide budget on May 2018, and the Lalitpur Metropolitan City had approved its Program and Policies for the fiscal year on July 2018 through its Second Nagar Sabha ${ }^{3}$ (Nepal Ministry of Finance, 2018; Lalitpur Metropolitan City, 2018). The local people in the settlement got the news of the budget allocation for the temple works, after the sixth month of the budget announcement from the central ministry and after the fourth month of approval of program and policies from the local government. However, local people were happy and excited that their temple was being renovated through the government fund. But they had pressure to complete the work in the next seven months, by mid-July 2019, because the fiscal year would last at that period. One of the members of Guthi, Secretary pointed:

A discussion was held about the budget allocation to our temple on the Guthi meeting. On its afternoon, I went to the Lalitpur Metropolitan office at Pulchowk to purchase the program demand book, which contains the forms for the formation of the consumer committee, monitoring committee, and the sample of the recommendation letter from ward office. The book had to be filled by the community people and submitted to the metropolitan office with a request to release the allocated fund. However, on the first day (December 26, 2018), I could not buy the book as it was out of stock. So, I again went to Pulchowk on the next day and purchased three books for NRs. 200. After reviewing it, I got confused about its filling process. It was my first time, and nobody was there to orient me. I planned to discuss the matter in our tole's meeting.

It could be interpreted that although the nearest local government unit is the ward office, the consumers have to travel a long distance to buy program demand books of the development activities. Besides, there is no help desk in the Metropolitan office and ward offices to assist the novice development volunteers, which could counsel them about the types of the forms, their filling processes, and necessary documents to be attached. Secretary shared the forms, with all the Guthi members and re-informed about the released budget. He also conveyed that the Guthi had to bear ten percent of the budget as the people's participation fund by forming a consumer committee among the beneficiaries. To our dismay, the majority of the Guthi members did not show any interest to discuss the matter. Secretary described that

I thought everybody would be excited to hear about the allocation of the fund from the local government to our place. However, the scenario was different. Most of the members fled away from the meeting. Some people, who showed the interest, pointed towards me to form a Upabhokta samiti ${ }^{4}$ myself. In addition, one of them skeptically blamed me that by collecting the signatures of the Guthi members, I would misuse the budget. I was demoralized at that time because there was neither teamwork nor an environment of trust.

The view of Secretary revealed that the development plan to fence the temple premise seemed not the prioritized need of the Guthi people. Upon discussion, he pointed out that people had different priorities such as drinking water, sports ground, blacktopped road, and solar streetlights. The ward office might have prepared the top-down model of the development plan and endorsed it. Otherwise, the

3 Municipal Council Meeting

4 Consumer committee

Nepalese Journal of Development and Rural Studies, Volume 16, 2019 
Guthi, which has thirty households and a budget saving of more than NRs. 6,00,000, was institutionally not interested in implementing the plan that could benefit them.

The Guthi did not show interest to discuss on the issue of forming the consumer committee and utilizing the fund allocated by the Metropolitan office. The hidden reason behind it was that if anybody showed interest to talk on that issue, he/she had to lead the process. Every member was scared to deal with the web-type bureaucratic system in the Metropolitan office in getting the allocated budget. Also, most of the Guthi members were job employees, businesspersons or engaged some where they did not have free time to go to the Metropolitan office for initiating the process.

Despite this fact, the ward office continuously gave pressure to the local Guthi members to form the consumer committee; otherwise, the budget was going to be freeze. After two months in February 2019, Guthi agreed to release NRs. 70,000 from it's saving for the construction work. I just verified the date seeing the meeting minute of the Guthi's meeting. Till that period also, none of the members were interested to work voluntarily as the consumer committee members. However, some youths of the Guthi realized that without the committee formation, the released budget would not come to the community and the fencing work at the temple premises would not begin. Therefore, they formed a committee comprising a team of eleven members. The chairperson of the committee, Mr. Chairperson-A said:

I and my friend Secretary realized that we should not miss that opportunity for developing our place. In addition, Guthi was providing people's participation fund, so we facilitated the forming of the committee. We made a jumbo committee of eleven members. We interacted a lot, but it was very difficult for us to find interested 33 percent female and involve them in the committee as per the norms of the Metropolitan office. So, we picked up some names and wrote them in the meeting minute. It was also difficult to get the females to participate in the monitoring and facilitation committee. So, we just wrote the names of two females, which were from different tole. Finally, we succeeded in forming a working committee on March 11, 2019. This narration of Chairperson-A signifies that the ritual committee was formed as it was very difficult to find the interested and capable members to work voluntarily in the committee. The monitoring and facilitation committee, which has an important role in inspecting the development works and easing any hurdles during implementation, was also formed by picking the names rather than seeing the interest, expertise, and efficiency of the members. Finally, the formal process of committee formation was completed, and Secretary and Chairperson-A went to the Metropolitan office on March 13, 2019, with all necessary documents and NRs. 70,000 cash to deposit as people's participation fund. Secretary remembered:

On that day, we were very excited that we were close to getting the fund from the office as we had already prepared a long list of documents. But as we went to the Metropolitan office, one of the officers there scanned our file and said that we had missed many other important documents. She suggested that the file should include the following things:

\footnotetext{
S.N. Headings

1 Consumer committee formation minute, with 33\% female representation and at least a person among the president, secretary, and treasurer must be female

2 Monitoring and Supporting Committee formation form
} 
3 Drawing on field sketch, location plan and preparing work plan and estimate of the work

4 Photos of the location before the start of the work

5 Filling up the form no. 01 and 02 provided by Metropolitan office including the recommendation from the ward office

6 Photocopies of the citizenship certificates of all 11 committee members

$7 \quad$ 1Tax clearing certificates of any three persons involved in the committee ${ }^{2}$

8 Minute of all committee members assuring to pay the 10 percent participation fund

9 Bank voucher showing the payment of 10 percent participation fund

10 Fund demand minute of the first installation (optional)

Secretary further said:

(Field Study, 2019)

We were unaware of those requirements. Although we had already managed, some of them, most of the criteria of the Metropolitan City were quite difficult and time-consuming to achieve. We returned home on that day. Afterward, we tried a lot to collect the remaining documents. It was difficult for us to get the technical documents from the ward engineer as he used to come to our ward only on Wednesday, Thursday, and Friday, and on other days, he was assigned to work in another ward office. So, it was a hectic process to meet him and prepare the documents. Finding the latest tax clearing certificates from any three committee members was also not easy as most of the committee members had not paid their Municipal for a long period. We were nearly hopeless because we had our own personal and professional works and the bureaucratic criteria of the Metropolitan city were not easy to understand.

Finally, all the necessary documents were collected and prepared by the consumer committee. After the twenty-six days of the committee formed at the settlement, the consumer committee and the Metropolitan office signed the agreement on April 6, 2019. The officials at the Metropolitan office told the Chairperson-A to collect the account payee cheque of the first installment after three days i.e. on April 9, 2019. By the agreement, we needed to complete the work within mid-July 2019. The committee had got just three months to finish the work.

Similarly, Chairperson-B faced tough trouble because of his age and educational status. He roamed from the door to door of the metropolitan office but could not find the way outs about receiving the released fund. He was also voluntarily contributing to the local development works. Instead, he became discouraged by the chaotic process in the Metropolitan office. He revealed:

"Kahile kata ja vancha! Kahile kata ja! Ma budo hinda-hinda thakaisake. Kun dasa bigrera ma yo samiti ma basichu (The officials of Metropolitan office tell me to go to different departments time and again. I am old and tired of roaming from door to door. Now, I feel regretful in working as a volunteer community worker). There is no one here to help me. Neither the details of procedures are written on Nagarik Badapatra ${ }^{5}$. If I was informed and oriented by the ward office about the process at the earlier phase, I would not face such difficulties. Our ward office has five elected representatives, one secretary appointed by the Government of Nepal, one social-mobilizer, one office assistant but they are also unaware of this process. This gave me a lot of trouble.

5 Citizens' charter

Nepalese Journal of Development and Rural Studies, Volume 16, 2019 
The experiences of Secretary and two Chairpersons reveal the bitter fact that the novice public consumer committees are not aware and oriented about the proper documentation process needed to get development funds from the local governments. Even the ward offices do not know about the processes. The Metropolitan office has not delegated authority to ward offices to collect the necessary documents from the consumer committees regarding getting the development budget. Therefore, people have suffered many troubles. The case is more severe when the community volunteers are senior citizens and not well educated.

\section{Post Agreement Process: Banking Hurdles}

The trouble of Consumer committee-A was not still ended. The Lalitpur Metropolitan office does not give direct cash to the consumer committees to start the agreed development work. The committee members must open a bank account in Nepal Bank Limited, Gahabal Section, Lalitpur. There is no option of choosing nearby or other banks or even other branches of Nepal Bank Limited. After a month of lengthy work in preparing, collecting, and submitting the necessary documents, and signing an agreement with the Metropolitan office, the committee faced the problems related to the bank. Mr. Chairperson-A recalled:

We prepared a meeting minute signed by all committee members mentioning the opening of the joint account in the names of the chairperson, secretary, and treasurer and went to the Gahabal bank. There we filled three different types of forms which were the personal information form, signatures sample form, and our institutional information form. Even we had to show our income source. I do not know why the bank was dealing with us as business professionals, as all the consumer committee members were doing voluntary work. We also needed to submit a recommendation letter from the Metropolitan office for the opening of the account. In the recommendation letter, the Metropolitan office had written that the registration certificate and the constitution of the formation of the committee were not needed to open the account.

Also, for opening the bank account, the chairperson, secretary, and treasurer had to be physically present in front of bank staffs with the original citizenship certificates. The whole process could be halted if we had not carried the stamp of our consumer committee. After we finished all the documentation process, the bank asked us to deposit NRs.1000 in the newly opened bank account for maintaining the minimum balance. Innocently we deposited the money and even did not dare to ask whether we would get it back or not. Even my mind was only focused on the signature, I put on the bank forms because if I could not maintain the same signature on the cheques, we could not withdraw our money. The bank staff asked us to come after three days to collect the cheque book from the reception.

The committee withdrew the first installment money on April 16, 2019, after the ten days of agreement with the Metropolitan office and after the thirty-six days of the consumer committee formation at the settlement. The process was delayed for some days because the treasurer of the committee was a jobholder and she had to manage her busy schedule for the physical presence in front of bank officials to open the account. The committee was a novice and not properly oriented with the processes at the ward office, municipal office, and bank, which put the members in many dilemmas. The experiences of Chairperson-A depict that preparing the documents for consumer committee formation 
and the hectic bank account opening processes have demoralized the voluntary development workers. There are no answers why the committee members, who are voluntarily providing time and effort for the development of their place, are asked to show their income details. In addition, there is no logic that the consumer committee, which has already provided 10 percent of the people's participation fund to the Metropolitan office, must deposit NRs. 1000 again to open the bank account as a minimum balance. Similarly, the account holders could make errors in the doing signatures in bank cheques. Mostly the senior citizens suffer from this problem. A digital thumb signature system could be an easy way to eliminate signature terror among the consumer committee members.

The hurdles faced by the consumer committees did not stop there. The consumer committee had to make a fact sheet, mentioning the details of the executing plan. It cost extra NRs. 500 to the consumer committee and they had to travel to the nearby city as the mostly flex ${ }^{6}$ printing offices were not locally available. Secretary pointed:

I placed the order to print the fact sheet at Lagankhel and it took two days. On the first day, I gave the order to print and on the second day, I received it. It would be better if the Metropolitan city office would provide the fact sheet during the time of signing the agreement. Can't a metropolitan office purchase a flex printing machine of its own and provide the printed fact sheet at a low cost if the fact sheet is so much important? Alternatively, the Metropolitan office could also provide an empty fact sheet containing the headings of information to be filled, and the respective consumer committees would fill the information themselves with the permanent marker.

These sufferings of the Secretary point that simply manageable things have been neglected by the Metropolitan and ward office. Likewise, there is no good coordination between metropolitan office and banking institutions and the people involved in the consumer committees have become victims. Giving authority of banking transactions to a single bank has again centralized the development system which has brought delays and hurdles only in the local works.

\section{Organizing and Mobilizing the Committee Members: A Chaos}

In urban centers, most of the people do not prefer to do volunteer work for community development because of their busy schedules and the hectic bureaucratic process. The gathering of the people is also difficult, where they could discuss different societal matters that affect their living. However, the indigenous community-based self-help groups like Guthi, Rodi, Bheja, Kipat, etc. have not only maintained our social and cultural activities but have brought people together (Shrestha, 2009). The gathering of people through these indigenous groups is also an important platform for information sharing and binding the people to achieve the common societal goals.

The four performances of teamwork comprise "context, composition, job design, and process" as described by Robbins and Judge, seem not completely fulfilled in community group making practices in the urban cities in Nepal (Robbins \& Judge, 2009 as cited in Dinitzen \& Jensen, 2010, p. 48). The inclusive composition in a team has become challenging because of the lack of interest of the beneficiaries to participate. The development plans are still crafted and endorsed through centralized mindsets without realizing, whether they are the real needs of the people or not. This system has weakened the feeling of ownership of the people in the development activities. Similarly, the novice

6 Temporary signboard

Nepalese Journal of Development and Rural Studies, Volume 16, 2019 
development workers, who want to develop their place by working in the consumer committees get frustrated and harassed many times because they are unaware of the administrative rules and regulations. Once they did participate in the consumer committee, they never will be engaged from the next time. Besides these, in our context, the facilitating role of local government is still missing to ease the process. Without this, the volunteer workers in the community are facing many troubles. As the municipal office is a part of the team of the whole process, it should ease the hurdles to encourage the volunteer spirit of the local people in developing their places by themselves.

\section{Networking Hurdles: A Resistance to the Local Development}

In the process of funds released to the local consumer committees, five organizations are actively involved which are the consumer committee, monitoring and supporting committee, ward office, metropolitan office, and bank. The first two committees represent the group of beneficiaries, which are the community people. The third and fourth bodies represent the local government units. The community people are the taxpayers and have the right to put development demands with their local governments. The local governments have the responsibility to address the need of its people as they are elected by and among the local people. To make the financial process transparent and accessible, the local governments have assigned the banking institutions.

As viewed by Pravan and Kenis (2007), there should be shared governance between the local people and the local government. This is because they have mutual trust with each other, and they have the common consensus to achieve the goal of local development. However, the scenario is just the opposite. The Metropolitan office is performing the role of lead governance and creating uneasy environments to the consumer committees by imposing dozens of rules without any prior information and orientation. Besides, the local government should have the lead governance towards the banking institutions, as the banks are a place to facilitate the fund releasing process. In contrast, the bank and the municipal office seem to have shared governance.

Lalitpur Metropolitan office has assigned banking authority to a single bank without clear and consumer-friendly frameworks. This situation has raised the question that whether the Metropolitan office is the lead organization or the bank in the local development process. In this case study itself, out of thirty-six days taken by a novice consumer committee-A, to get the allocated fund from Lalitpur Metropolitan City office, the Metropolitan bureaucracy consumed twenty-six days ( $72 \%$ of the time) and the banking procedures and consumed extra ten days ( $28 \%$ of the time). The details of the timelapse in this process have been shown below table (Table 1). 
Table 1. Project Duration

\begin{tabular}{|c|c|c|c|}
\hline Levels of Govt. & Heading & Date & $\begin{array}{l}\text { Remaining Days of the } \\
\text { Fiscal Year 2075/76 }\end{array}$ \\
\hline Central Govt. & $\begin{array}{l}\text { The budget announcement by Nepal } \\
\text { Government }\end{array}$ & 29-May-18 & 413 \\
\hline Local Govt. & $\begin{array}{l}\text { Program and Policies approved by Lalitpur } \\
\text { Metropolitan City }\end{array}$ & 11-Jul-18 & 370 \\
\hline \multirow[t]{5}{*}{ Ward/Settlement } & Discussion at Tole meeting & 26-Dec-18 & 202 \\
\hline & Consumer committee formation & 11-Mar-19 & 127 \\
\hline & $\begin{array}{l}\text { Agreement signed with Lalitpur } \\
\text { Metropolitan Office }\end{array}$ & 6-Apr-19 & 101 \\
\hline & $\begin{array}{l}\text { Cheque of First installment provided by } \\
\text { Lalitpur Metropolitan Office }\end{array}$ & 9-Apr-19 & 98 \\
\hline & $\begin{array}{l}\text { Banking process completed; money } \\
\text { withdrawn \& work started }\end{array}$ & 16-Apr-19 & 91 \\
\hline Project deadline & End of Fiscal year 2075/76 (2018/19) & 16-Jul-19 & 0 \\
\hline
\end{tabular}

(Field Study, 2019)

The table 1 shows that, although the Central Government and Metropolitan Office had timely announced the budget for the fiscal year, the discussion of the development plan at the settlement began quite late. The table also shows a pity picture that the consumer committee -A had only three months to complete the assigned work of temple reconstruction. The remaining period for completing the work by the consumer committee-A was from 16-Apr-19 to 16-Jul-19, which was primarily the summer monsoon season in Nepal (Pokharel, 2015). There was no option left, and the committee completed work by the time despite the monsoon rains. This "Barkhe bikas ${ }^{7}$ " aspect is the taken for granted model of development works in Nepal.

There is a constitutional provision that central government must present the annual budget for the upcoming fiscal year before the Federal parliament on the 15th day of Jestha ${ }^{8}$ every year (Government of Nepal, 2015). There is another legal provision in Local Government Operation Act 2017, that the annual budget at every municipality and rural municipalities should be presented at the council's meeting by 10th of Asar ${ }^{9}$ every year. After the approval of the budget from the council, the Local governments should commission the programs and budget to the respective department heads at Municipal offices and the ward secretaries within the next 22 days (Government of Nepal, 2017). Despite these, there are no clear mentioning about the time frame works for the budget distribution and spending for the consumer committees. The unclear and haphazard planning and implementation of the budget have become problematic at ward and settlement levels, which are the implementing agencies as well. Thus, the chaotic system must be completely transformed and there should be shared governance between the local government and the local beneficiaries, whereas the Metropolitan office should also lead in designing the consumer-friendly banking policies.

7 Physical development works during the rainy season

8 Usually May 28 or 29

9 Usually June 24 or 25

Nepalese Journal of Development and Rural Studies, Volume 16, 2019 


\section{Winding Up}

The initiative of novice development workers by organizing themselves into consumer committees in urban centers is praiseworthy. However, it can be difficult to unite and mobilize the members for achieving common societal goals in urban societies. Therefore, the ward offices should lead the process of consumer committee formation, as the local government operation Act 2017 has made this mandatory (Government of Nepal, 2017). The organization theory, which defines the four performances of a team formation such as the context, composition, job design, and process, should not be limited in case of consumer committee formation in the urban cities in Nepal. The ward office should facilitate in easing the team formation, budget release, and budget implementation process through appropriate rules, orientation processes, and time planning. These indicators must be contextualized as per the community's needs and social structure so that everyone can show their interest in doing voluntary participation in the development process, and the development works is initiated and completed by the scheduled time. Likewise, the networking between the government line agencies must be concentrated on creating people-friendly policies. There must be a shared governance system between the local government and local beneficiaries so that both parties equally contribute to the development efforts. Clearly, the local government should have the lead governance towards the banking process where the novice consumer committees can get the released budget without facing the tough bureaucratic banking systems.

\section{References}

Adhikari, R. (2010). Local governance institutions in Nepal: Status and challenges. Retrieved from: https://www.academia.edu/1831963/Local_Government_Institutions_in_Nepal_Status_and_ Challenges on 17-June -2018

Chalise, B. K., \& Varughese, G. (2017). Why Nepal's upcoming local elections matter more than ever? Retrieved from: https://asiafoundation.org/2017/04/26/nepals-

Chambers, R. (1983). Rural development: Putting the last first. London: Longman Publication.

Dinitzen, H. B., \& Jensen, L. K.(2010). Organizational theory: A practical approach. Denmark: The author and Hans Reitzels Forlag.

Government of Nepal. (1990). The constitution of the kingdom of Nepal (1990)). Kathmandu: Nepal Law Commission.

Government of Nepal. (1999). Local self-governance act 1999. Kathmandu: Author.

Government of Nepal. (2007). The interim constitution of Nepal 2007. Kathmandu: Nepal Law Commission.

Government of Nepal. (2015). The new constitution of Nepal 2015. Kathmandu: Nepal Law Commission. Government of Nepal. (2017). Local government operation act 2017. Kathmandu: Author.

Government of Nepal. (2018). Final district 1-75 corrected last for Rajpatra. Retrieved from http:// www.mofald.gov.np/en/nepal-nagarpalika-gaupalika-list retrieved on 17-June-2018

Halgin, D. S. (2012). An introduction to social network theory. Retrieved from https://jesuitnetworking. org/wp-content/uploads/2013/10/ Halgin_Social_Network_Theory.pdf on 13-Jun-18

Hope, K. R. (2000). Decentralization and local governance theory and the practice in Botswana. Development Southern Africa, 17(4), 519-534. Retrieved from http://dx.doi. org/10.1080/03768350050173912 
Lalitpur Metropolitan City. (2018). Dosro nagar sabha ko nirnayaharu (Decisions of second Municipal council). Lalitpur: Author.

Nepal Ministry of Finance (2018). Budget speech of fiscal year 2075/76. Kathmandu: Author.

Nepal National Planning Commission (2016). Fourteenth plan (2073/74-75/76). Kathmandu: Author.

Pokharel, A. K. (2015). Distribution of rainfall intensity during the summer monsoon season over Kathmandu, Nepal. Royal Meteorological Society, 70(9). Retrieved from https://doi. org/10.1002/wea.2544

Provan, K. G., \& Kenis, P. (2007). Modes of network governance: Structure, management and effectiveness. Journal of public administration and theory. Oxford University Press.

Shrestha, M. (2009). Community development in Nepal: Past and present Practices. Community development: Kathmandu: Quest Publications.

Tripathi, H. B. (2016). The constitution of Nepal: A critique. NJA Law Journal. Retrieved from: https://www.academia.edu/28616758/The_Constitution_of_Nepal_A_Critique upcominglocal-elections-matter-ever/ on 17-June-2018

Willis, J.W. (2007). Foundation of qualitative research. USA: Sage publications.

Yin, R. K. (2011). Case study research: Design and methods (5th ed.). Los Angeles: Sage Publications. 